\title{
Breeding Brassica napus for Shatter Resistance
}

\author{
S. Hossain ${ }^{1 *}$, G.P. Kadkol², R. Raman ${ }^{3}$, P.A. Salisbury ${ }^{1,4}$ and H. Raman ${ }^{3}$ \\ ${ }^{1}$ Department of Primary Industries, \\ ${ }^{2}$ NSW Department of Primary Industries, \\ Tamworth Agricultural Institute \\ ${ }^{3}$ EH Graham Centre for Agricultural Innovation, \\ an alliance between NSW Department of Primary \\ Industries and Charles Sturt University, \\ Wagga Wagga Agricultural Institute, \\ ${ }^{4}$ Department of Agriculture and Food Systems, \\ Melbourne School of Land and Environment, \\ The University of Melbourne, \\ Australia
}

\section{Introduction}

Brassica napus (canola or oilseed rape) has emerged as an important cultivated oilseed crop species grown in temperate climates of both the northern and southern hemispheres. In 2009, canola was sown to approximately 23.8 million hectares worldwide and production was approximately 53.3 million tonnes (FAOSTAT, 2011). The name "canola" identifies the "double low" oil and meal quality (low erucic acid content in the oil and low glucosinolate content in the meal) of the crop. Innovations such as herbicide resistance have enhanced the value of canola in weed management and crop rotations and improved its profitability. Further oil quality improvements have resulted in specialty canola varieties producing high oleic and low linolenic acid oils suitable for frying applications. However, one requirement that has persisted through the relatively short history of domestication of B. napus is the need for substantial improvement in shatter resistance to prevent significant seed loss especially under adverse harvest conditions.

Dehiscence of siliqua due to external forces at or after maturity leads to siliqua shatter (Kadkol et al., 1986a). Siliqua shatter can occur both prior to harvest due to adverse weather conditions and at harvest due to impact from combine harvesters. Dehiscence of ripe, dry fruit is a natural process by which many plant species disperse their seed in order to survive and spread in the wild. Whilst this mechanism is advantageous in nature, siliqua dehiscence in agriculture results in significant yield loss. Moreover, the dehisced seed can persist in the soil up to 10 years in winter B. napus, giving rise to volunteer plants or weeds in subsequent crops (Pekrun et al., 1996; Gulden et al., 2003). Typically yield losses are in the range of $10 \%$ $25 \%$ (Price et al. 1996). Seed losses of as much as 50\% of expected yield have been reported when adverse climatic conditions delayed harvesting (MacLeod, 1981; Child \& Evans, 1989). Current cultural practices to reduce siliqua shatter and to achieve better uniformity of 
ripening for harvest include windrowing (or swathing) and spraying desiccants. However, both these practices add to the cost of production and reduce flexibility in farm operations (Kadkol, 2009). Increased inherent shatter resistance could provide an option to delay harvesting to allow more even maturing of seeds and decrease the incidence of chlorophyll contamination from immature seeds in extracted oil (Morgan et al., 1998).

The fruits of Brassicaceae are botanically known as siliquae. Siliquae are derived from two carpels that form two locules separated by a thin, papery white replum. The fruit walls are valves that are attached to the replum forming a suture. The siliquae are attached to the raceme by a pedicel at the proximal end. At the distal end is the beak formed by the style (Fig 1). The suture is also known as dehiscence zone (DZ), where the valve margin is connected to the replum. Typically, a layer of thin parenchyma cells, that acts as a separation layer upon ripening, connects the valve margin to the replum. Dehiscence is usually initiated at the proximal end of the siliqua.

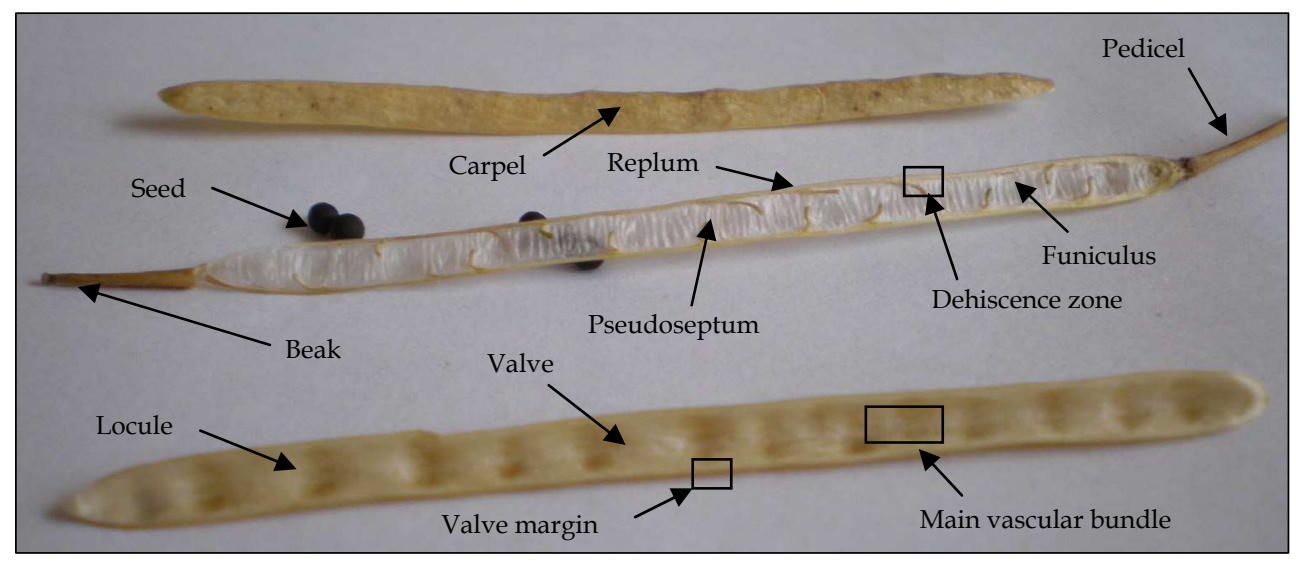

Fig. 1. The main structural features of a Brassica napus seed siliqua (from Kadkol, 2009)

Kadkol et al. (1986a) showed the presence of an abscission layer in the suture of siliquae of shatter susceptible Brassica napus and its absence in shatter-resistant Brassica rapa (Fig 2). They suggested that presence of an abscission layer is the basis of shatter susceptibility of $B$. napus. Differences in the vascular structure of siliquae and the width of the DZ has also been reported to be associated with variation for shatter resistance in a resynthesized $B$. napus line, 'DK142' in comparison with the shatter-susceptible winter B. napus line'Apex' (Child et al., 2003). The size of the main vascular bundle as it exited the valve and joined the vascular tissue of the replum was much larger in the resynthesized line.

Picart and Morgan (1984) investigated the physiological processes implicated in the control of siliqua dehiscence such as autolysis of the cells (degradation of pectic material in the middle lamella) of the DZ, senescence of the siliqua wall, water loss from thin walled cells, development of tensions resulting from different rates of drying of non-lignified and lignified cells of the valve and breakage of the vascular bundles at the base of the siliqua at the pedicel end. However, a study using polarizing microscopy by Kadkol et al. (1986a) suggested that development of tensions in the siliqua due to differential drying is unlikely. 
A number of possible factors involved in the expression of the siliqua shatter resistance include morphological, anatomical and biochemical aspects of siliqua development and physiology. It may even encompass biotic and abiotic stress factors (Kadkol et al., 1986a; Morgan et al., 1998; Morgan et al., 2003; Summers et al., 2003). A summary of siliqua and plant characters as well as other factors reported to be involved in siliqua shatter are presented in Table 1.

\begin{tabular}{|c|c|c|c|}
\hline Source of trait & Trait & Trait type & Reference \\
\hline \multirow[t]{10}{*}{ Siliqua } & Siliqua erectness & Morphological & Kadkol et al., 1984; Morgan et al., 2000 \\
\hline & Siliqua size, shape and weight & Morphological & $\begin{array}{l}\text { Morgan et al., 2000; Squires et al., 2003; Dinneny } \\
\text { and Yanofsky 2004 }\end{array}$ \\
\hline & Density of siliqua & Morphological & Kadkol et al., 1984 \\
\hline & Pedicel length & Morphological & Morgan et al., 1998; Kadkol et al., 1984 \\
\hline & $\begin{array}{l}\text { Lignification of the } \\
\text { suture/dehiscence zone }\end{array}$ & Anatomical & Kadkol et al., 1986a \\
\hline & Lignification of the siliqua valves & Anatomical & Morgan et al., 1998 \\
\hline & Size of main vascular bundle & Anatomical & $\begin{array}{l}\text { Child et al., 2003; Kadkol et al., 1989; Morgan et al., } \\
1998\end{array}$ \\
\hline & Size of the dehiscence zone & Anatomical & Child et al., 2003 \\
\hline & Enzymatic activity & Biochemical & Morgan et al., 1998; Child et al., 2003 \\
\hline & Hormonal activity & Biochemical & $\begin{array}{l}\text { Chauvaux et al., 1997; Child et al. 1998; Morgan et } \\
\text { al., } 1998\end{array}$ \\
\hline $\begin{array}{l}\text { Canopy } \\
\text { structure }\end{array}$ & Interaction between plants & Morphological & $\begin{array}{l}\text { Bowman, 1984; Kadkol et al., 1989; Summers et al., } \\
2003\end{array}$ \\
\hline \multirow[t]{6}{*}{ Plant } & Stem thickness & Morphological & Morgan et al., 1998 \\
\hline & Uniformity of flowering & Physiological & Chandler et al., 2005; Morgan et al., 1998 \\
\hline & Plant height & Morphological & $\begin{array}{l}\text { Morgan et al., 1998; Morgan et al., 2000; Summers et } \\
\text { al., } 2003\end{array}$ \\
\hline & Raceme structure & Physiological & Child \& Huttly, 1999; Summers et al., 2003 \\
\hline & $\begin{array}{l}\text { Angle of the branches to the } \\
\text { main stem }\end{array}$ & Morphological & Kadkol et al., 1984; Child \& Huttly, 1999 \\
\hline & Number of primary branches & Morphological & Kadkol et al., 1984 \\
\hline \multirow{3}{*}{$\begin{array}{l}\text { Abiotic } \\
\text { factors }\end{array}$} & Temperature & Environmental & Morgan et al., 2003; Summers et al., 2003 \\
\hline & Rain and drought & Environmental & Morgan et al., 2003; Summers et al., 2003 \\
\hline & Time of sowing & Environmental & Summers et al., 2003 \\
\hline \multirow[t]{2}{*}{ Biotic factors } & Pests e.g. siliqua midge, aphids & Environmental & Meakin \& Roberts , 1991; Summers et al., 2003 \\
\hline & Pathogens e.g. alternaria & Environmental & Morgan et al., 2003 \\
\hline
\end{tabular}

Table 1. Morphological, anatonomical, biochemical, physiological and environmental attributes implicated in siliqua shatter

\section{Biochemical and molecular mechanisms underlying shatter resistance}

Dehiscence of siliquae occurs as a result of highly coordinated and regulated events in growth and differentiation of the DZ and the degradation of the separation layer at ripening. This is due to triggering of enzymatic activity in DZ and cell separation predisposing siliqua to dehiscence from external forces. Several genes involved in growth and differentiation of the DZ have been identified and studied in Arabidopsis (e.g. Sorefan et al., 2009). 


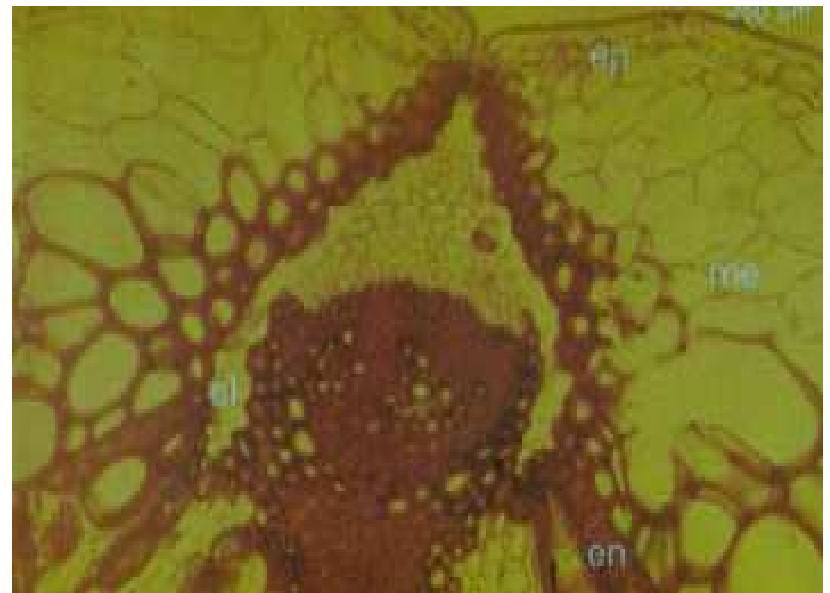

(a)

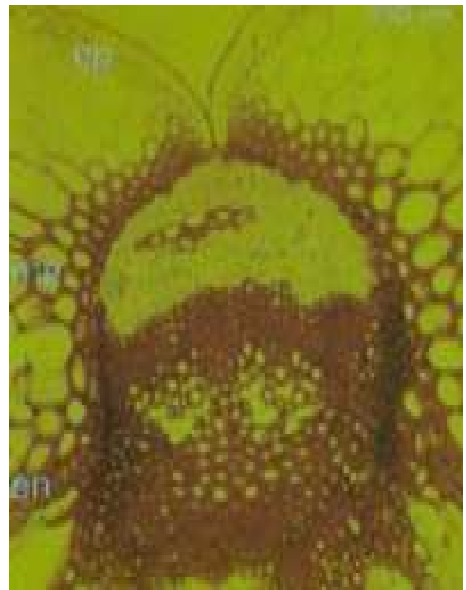

(b)

Fig. 2. Transverse sections (x120) of fresh siliquae of B. napus (2a) and B. rapa cv. DS17D (2b) through dehiscence zones, stained with phloroglucine $(\mathrm{al}=$ abscission layer, en $=$ endocarp, me $=$ mesocarp, ep $=$ epicarp) (from Kadkol et al., 1986a)

Many growth regulators such as abscicic acid (ABA), ethylene and auxin are well known for their role in abscission (Nemhauser et al., 2000; Ferrándiz, 2002; Sohlberg et al., 2006; Child et al., 1998; Meakin \& Roberts, 1990b; Roberts et al., 2002). In Brassica, the role of an abscission cell layer in the siliquae dehiscence was first investigated by Kadkol et al. (1986a). Dehiscence is caused by the loss of cellular cohesion in the abscission layer, primarily attributable to the degradation of the middle lamella which appeared to result from an increased activity of hydrolytic enzyme cellulase leading to the cell separation process (Meakin \& Roberts, 1990a; Meakin \& Roberts, 1990b).

Johnson-Flanagan and Spencer (1994) found a climacteric of seed-produced ethylene preceding the pre-desiccation phase of $B$. napus. The evidence for ethylene acting as a regulator of dehiscence is unclear but it could still be a trigger for cellulase activity in DZ. Child et al. (1998) observed a correlation between delayed shattering and reduced ethylene production. The suppression of ethylene production by the treatment of siliquae with amino-ethoxyvinylglycine (AVG) delayed siliqua shatter. However, Roberts et al. (2002) reported Arabidopsis mutants that have nonfunctional ethylene receptors still exhibit a normal time-course of siliqua dehiscence and that the elevation in the cellulase $\beta-1,4$ glucanase in B. napus DZ occurs when the ethylene level in the siliqua is falling.

The activity of hydrolytic enzymes including $\beta$-1,4-glucanase and polygalacturonase involved in cell separation in the DZ appears to be regulated by auxin (Coupe et al., 1993). Chauvaux et al. (1997) observed that a decrease in auxin content in the DZ just prior to moisture loss in siliquae was correlated with a tissue specific increase in $\beta$-1,4-glucanase activity and hence with siliqua dehiscence. Auxin appears to have the opposite effect to ethylene and negatively regulates $\beta$-1,4-glucanase. Sorefan et al. (2009) demonstrated that formation of a local auxin minimum is required for specification of the valve margin abscission layer in Arabidopsis where dehiscence takes place. Thus, a low level of auxin 
seems to be a prerequisite for siliqua dehiscence and may allow for the induction of the activity of cell wall degrading enzymes.

In addition to cellulase activity, dissolution of the middle lamella in the DZ is another important process leading to cell separation. Jenkins et al. (1996) and Petersen et al. (1996) cloned and characterised two DNA fragments, SAC66 and RDPG1 associated with an endopolygalacturonase (endo-PG). Both the DNA fragments related to a single Arabidopsis ortholog (called SAC70). Both transcriptional and post-translational control of PG activity has also been proposed (Roberts et al., 2002; Sander et al., 2001). However, in contrast to the activity of the cell wall degrading enzyme $\beta$-1,4-glucanase, polygalacturonase exhibits no correlation either temporally or spatially with siliqua dehiscence (Meakin \& Roberts, 1990). This lack of siliqua DZ specificity of the endo-PG promoter has prevented the engineering of shatter resistance by silencing the endo-PG (Ostergaard et al., 2007).

\section{Methods for screening germplasm for shatter resistance}

Many of the early assessments used to evaluate siliqua shatter resistance have been based on imprecise, visual field observations (e.g., harvest yield and visual assessments) or manual tests (Table 2). These tests are somewhat subjective and are often not necessarily comparable due to the difference in maturity and moisture status of siliquae or differences in environmental conditions (Morgan et al., 1998).

\begin{tabular}{|c|c|c|c|}
\hline Approach & Type & Measure & Reference \\
\hline \multirow{5}{*}{$\begin{array}{l}\text { Field } \\
\text { observations }\end{array}$} & Visual scoring & Index & Josefsson, 1968 \\
\hline & $\begin{array}{l}\text { Direct harvesting vs. } \\
\text { windrowing }\end{array}$ & Yield & Josefsson, 1968 \\
\hline & $\begin{array}{l}\text { Number of volunteer plants } \\
\text { after harvest }\end{array}$ & Plants/area & Josefsson, 1968 \\
\hline & Seed counting after harvest & $\%$ seed loss & Josefsson, 1968 \\
\hline & Count shattered siliquae & $\%$ shattered siliquae & $\begin{array}{l}\text { Tomaszewski \& } \\
\text { Koczowska, } 1971\end{array}$ \\
\hline \multirow[t]{3}{*}{$\begin{array}{l}\text { Mechanical } \\
\text { test }\end{array}$} & $\begin{array}{l}\text { Compress plants between } \\
\text { plates }\end{array}$ & $\%$ shattered siliquae & $\begin{array}{l}\text { Jakubiec \& } \\
\text { Growchowski, } 1963\end{array}$ \\
\hline & Vibrate whole plants & $\%$ shattered siliquae & Voskerusa, 1971 \\
\hline & $\begin{array}{l}\text { Squeeze siliquae between } \\
\text { fingers }\end{array}$ & Index & $\begin{array}{l}\text { Tomaszewski \& } \\
\text { Koczowska } 1971\end{array}$ \\
\hline $\begin{array}{l}\text { Anatomical } \\
\text { test }\end{array}$ & $\begin{array}{l}\text { Size of sclerenchymatic bridges } \\
\text { between valves and replum }\end{array}$ & $\begin{array}{l}\text { Thickness of } \\
\text { sclerenchymatic bridge }\end{array}$ & Loof \& Jonsson 1970 \\
\hline
\end{tabular}

Table 2. Early tests used to identify shatter resistance in Brassica species

Kadkol et al. (1984) suggested that the methodology used to test siliqua shatter resistance should simulate shattering as it occurs in the field and during harvesting. They further 
suggested that it would be most appropriate to test the siliqua as a cantilever because most external forces acting on the siliqua would load it at the distal end whilst it is attached to the plant at the proximal end. However, many of the mechanical tests (Table 3) including the random impact test do not achieve this requirement. Another requirement of testing procedures is that they should be low cost, fast and efficient. This criterion is not met by tests of the DZ that involve considerable preparation of the sample and subsequent technical demanding analysis.

To date, several mechanical testing procedures have been employed to investigate shatter resistance (Table 3) which allowed for greater comparability, accuracy and repeatability across different lines and cultivars. Liu et al. (1994) developed a pendulum-based test (Fig 3) that was a further development from the quasi-static cantilever test developed by Kadkol et al. (1984). The use of a pendulum provided a dynamic cantilever test of the siliquae that simulates the natural process in the field and achieves rates of loading comparable to those in the field. Recently, Kadkol (2009) reported further refinements of computer software and the apparatus for the pendulum test (Fig 4) which have improved the efficiency of the process as a screening method for use in breeding.

\begin{tabular}{|c|c|c|c|}
\hline Name of the test & Purpose & Methodology & Reference \\
\hline $\begin{array}{l}\text { Manual bending } \\
\text { test }\end{array}$ & $\begin{array}{l}\text { Evaluate shatter } \\
\text { resistance }\end{array}$ & $\begin{array}{l}\text { Collected siliqua placed on flat surface } \\
\text { with angles marked and with pedicel } \\
\text { held firm. The siliqua is bent } \\
\text { anticlockwise causing bending stress at } \\
\text { which the angle is noted (this bending } \\
\text { stress is similar to wind stress in field). }\end{array}$ & Roy, 1982 \\
\hline Cantilever test & $\begin{array}{l}\text { To measure the } \\
\text { bending moment } \\
\text { and energy } \\
\text { required to cause } \\
\text { siliqua fracture }\end{array}$ & $\begin{array}{l}\text { Siliqua is clamped at the pedicel end in a } \\
\text { Universal Testing Machine. A steel wedge } \\
\text { fixed to the load cell was used to load the } \\
\text { siliqua as a cantilever, the applied force is } \\
\text { recorded on the chart. Shatter resistance } \\
\text { was defined as the bending moment at the } \\
\text { peak of the force displacement graph. } \\
\text { Another measure of shatter resistance was } \\
\text { energy measured as the area under the } \\
\text { curve up to the peak. }\end{array}$ & $\begin{array}{l}\text { Kadkol et } \\
\text { al., } 1984\end{array}$ \\
\hline $\begin{array}{l}\text { Microfracture } \\
\text { test (MFT) }\end{array}$ & $\begin{array}{l}\text { To establish the } \\
\text { contribution of } \\
\text { the main vascular } \\
\text { bundle of the } \\
\text { valve to the } \\
\text { amount of energy } \\
\text { needed to } \\
\text { separate the valve } \\
\text { from the replum. }\end{array}$ & $\begin{array}{l}\text { Siliqua wall tissue is excised at the } \\
\text { pedicel end of the valve or from the } \\
\text { middle of the siliqua half-way between } \\
\text { pedicel and the beak in order to isolate } \\
\text { areas for testing that were } \sim 1 \mathrm{~mm} \text { in } \\
\text { length containing the septum and valve } \\
\text { between which the DZ was intact. An L- } \\
\text { shaped steel device is raised by a } \\
\text { Universal Test Machine until fracture } \\
\text { occurred. }\end{array}$ & $\begin{array}{l}\text { Child et } \\
\text { al., } 2003\end{array}$ \\
\hline
\end{tabular}




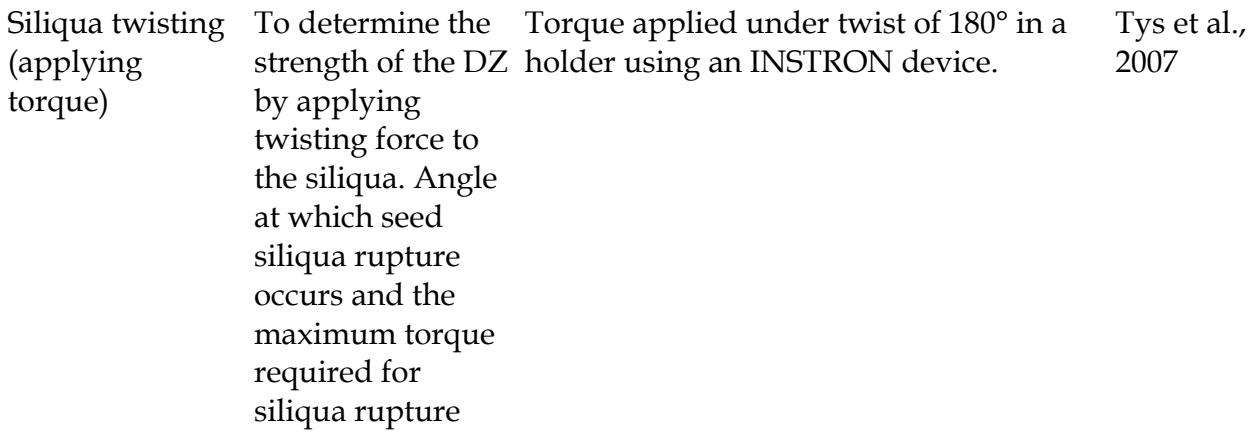

\begin{tabular}{|c|c|c|c|}
\hline $\begin{array}{l}\text { ‘Ripping’ } \\
\text { method }\end{array}$ & $\begin{array}{l}\text { To quantitatively } \\
\text { determine siliqua } \\
\text { dehiscence } \\
\text { strength at } 2.5 \mathrm{~cm} \\
\text { from pedicel }\end{array}$ & $\begin{array}{l}6 \text { siliqua per variety kept at } 25^{\circ} \mathrm{C} \text { and } \\
50 \% \text { RH for } 2 \text { weeks. A metallic thread } \\
\text { laced around the siliqua } 2.5 \mathrm{~cm} \text { from } \\
\text { pedicel and laced to the pedicel, siliqua } \\
\text { glued to plate. An L-shaped probe of the } \\
\text { texture analyser lifted thread and opened } \\
\text { siliqua; probe recorded opening strength. }\end{array}$ & $\begin{array}{l}\text { Tan et al., } \\
2007\end{array}$ \\
\hline Pendulum test & $\begin{array}{l}\text { To measure } \\
\text { energy absorbed } \\
\text { by the pendulum } \\
\text { in siliqua } \\
\text { rupturing process }\end{array}$ & $\begin{array}{l}\text { Siliqua is clamped vertically by its stalk } \\
\text { at the bottom dead centre of the } \\
\text { pendulum swing. An optical encoder is } \\
\text { used to measures the loss of pendulum } \\
\text { movement upon striking and shattering } \\
\text { the siliqua which provides an estimate of } \\
\text { the energy absorbed by the siliqua. }\end{array}$ & $\begin{array}{l}\text { Kadkol et } \\
\text { al., 1991; } \\
\text { Liu et al., } \\
1994\end{array}$ \\
\hline $\begin{array}{l}\text { Random Impact } \\
\text { Test (RIT) }\end{array}$ & $\begin{array}{l}\text { Measure breaking } \\
\text { response of } \\
\text { siliqua by } \\
\text { mimicking } \\
\text { conditions in the } \\
\text { crop canopy } \\
\text { caused by } \\
\text { agitation during } \\
\text { harvest or caused } \\
\text { by poor weather } \\
\text { conditions, fit a } \\
\text { model and } \\
\text { estimate half life } \\
\text { of sample }\end{array}$ & $\begin{array}{l}\text { Equilibrate siliqua in atmosphere of } \\
\text { constant relative humidity }(50 \%) \text { and } \\
\text { temperature }\left(105^{\circ} \mathrm{C}\right) \text { to achieve constant } \\
\text { weight; } 20 \text { siliqua per sample ( } 2 \\
\text { replications), Controlled agitation of } \\
\text { sample in a receptacle (cylindrical of } \\
20 \mathrm{~cm} \text { diameter, axis vertical) containing } 6 \\
\text { steel balls }(12.5 \mathrm{~mm} \text { diameter) and shaken } \\
\text { in the horizontal plane, } 17 \text { seconds ; } \\
\text { remove siliqua and classify them as } \\
\text { shattered or intact. }\end{array}$ & $\begin{array}{l}\text { Bruce et al. } \\
\text { (2002); } \\
\text { Morgan et } \\
\text { al. (1998; } \\
\text { 2003); } \\
\text { Squires et } \\
\text { al. (2003) }\end{array}$ \\
\hline
\end{tabular}

Table 3. Recent attempts to evaluate siliqua shatter resistance. 


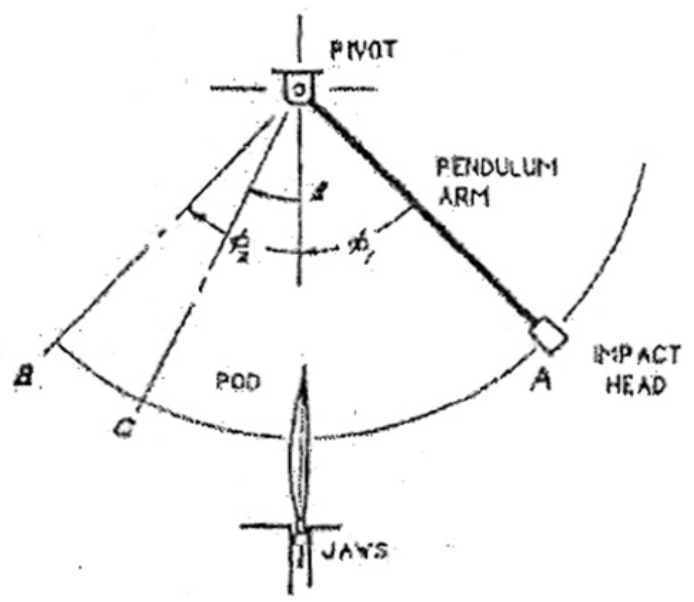

Fig. 3. Arrangement and analysis of pendulum (from Liu et al., 1994).

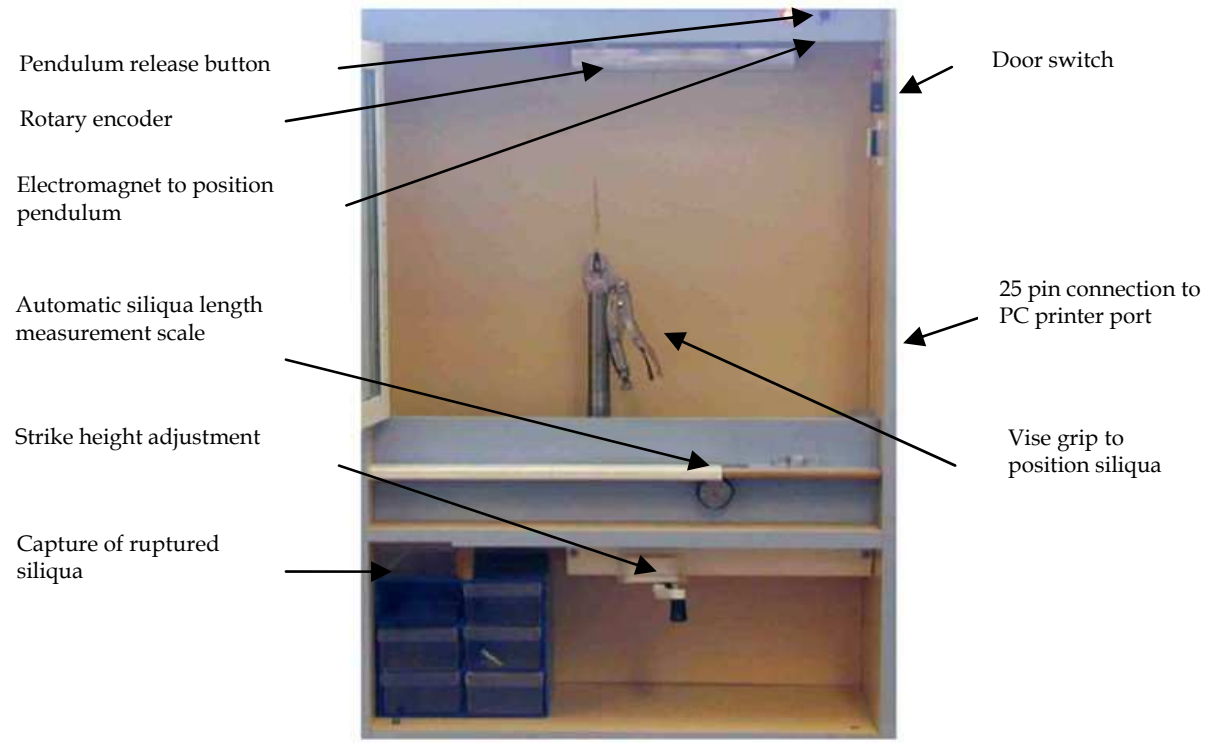

Fig. 4. The new pendulum machine for testing Brassica siliquae.

Morgan et al. (2003) cited the random impact test (RIT) as a good overall measure to compare the relative susceptibility of lines. The RIT involves agitation of 20 siliquae with ball bearings for $20 \mathrm{~s}$ and counting the number of intact siliquae. This test does not simulate the process of shatter as it happens in the field. These authors also quoted the tensile strength test as a useful test which correlates well to the RIT and field scores of shatter. However, the test appears to involve considerable sample preparation and hence is unsuitable for application in breeding programs. Wang et al. (2007) compared the degree of 
correlation between field data and results from pendulum test and RIT. Although it is difficult to accurately quantify harvest losses due to shatter in the field, in the study of Wang et al. (2007), RIT showed a lower level of association with field shatter than the pendulum test.

Morphological characters associated with shatter are more difficult to quantify. Delayed harvesting restricts the accuracy and effectiveness in discriminating between small differences in shattering affected by climatic and other environmental factors such as bird damage.

\section{Genetic variation for shatter resistance}

Genetic variation for shatter resistance exists both within Brassica species including B. rapa L., B. juncea L., B. hirta L. and within wild relatives of Brassica (Kadkol et al., 1985; Wang et al., 2007). Although there is some variation in B. napus, the level of resistance available is generally considered inadequate to avoid windrowing of crops on a routine basis (Raman et al., 2011). There have been a small number of reports characterizing genetic variation for shatter resistance in Brassica in germplasm collections. Wen et al. (2008) investigated the siliqua shattering resistance index of 229 accessions (mostly of Chinese origin) of B. napus using RIT. Most of the accessions (59.4\%) were very susceptible to siliqua shatter. However, there were two lines considered to be shatter resistant which could potentially be used as parents to develop new varieties for improved this trait. Peng-Fei et al. (2011) evaluated 220 lines of B. napus for shatter resistance using 'ripping' method (Tan et al. 2007) and showed that ripping force ranged from $1.46 \mathrm{~N}$ to $4.23 \mathrm{~N}$. The levels of pod strength reported in this study appear to be in general agreement with studies in Australia (Kadkol et al., 1984; Raman et al., 2011) indicating limited genetic variation in B. napus. Raman et al. (2011) evaluated 181 accessions of Brassica napus, one B. rapa, three B. juncea and two accessions of B. carinata, using a pendulum test (Kadkol, 2009) in two separate experiments. These accessions were collected from different parts of the world, representing contemporary cultivars and elite lines from Australian and international programs for shatter resistance. There was a moderate degree of correlation between the two sets of data. Siliqua strength (rupture energy - RE) values varied from 2.09 to $5.28 \mathrm{~mJ}$ and 2.34 to $5.58 \mathrm{~mJ}$ respectively, in the two experiments, indicating good correspondence between the two trials. These levels of $\mathrm{RE}$ are associated with intermediate shatter resistance which could prevent pod shatter in standing crops but insufficient to prevent harvest shatter (Kadkol, 2009). Genetic variation for higher levels of siliqua strength necessary for resistance to harvest shatter is present in $B$. rapa vars Yellow Sarson and Brown Sarson (Kadkol et al., 1984; Liu et al., 1994; Mongkolporn et al., 2003; Kadkol, 2009). Shatter resistance could be improved by introgressing the trait from these types and B. juncea (Kadkol 2009; Raman et al., 2011).

\section{Inheritance of shatter resistance}

Kadkol et al. (1986b) considered the genetic variation for shatter resistance within B. napus to be limited and studied inheritance of shatter resistance (measured as siliqua strength) in $B$. rapa in crosses between Brown Sarson (shatter resistant) and Torch (shatter susceptible) and Yellow Sarson (resistant) and Torch (susceptible). Segregation in the $\mathrm{F}_{2}$ generation indicated the presence of 2 to 3 recessive genes which showed dominant epistatic interaction controlling shatter resistance. Further genetic analysis in one cross (Torch $x$ DS-17-D) 
showed the presence of significant non-additive and additive genetic variances and a high broad sense heritability of shatter resistance (Kadkol et al., 1986c). The degree of dominance for shatter resistance was close to one supporting results from Mendelian analysis. In a subsequent study, Mongkolporn et al. (2003) confirmed a phenotypic segregation ratio of 12:3:1 (susceptible: intermediate: resistant) in an $\mathrm{F}_{2}$ population derived from the Torch $\mathrm{x}$ DS17-D, which indicated two recessive major genes (sh1 and sh2) with dominant epistasis conferring the resistance. This supports the earlier findings of Kadkol et al. (1986b).

Morgan et al. (2000) reported that shatter resistance in B. napus was recessive and mostly determined by additive genes. In their study, correlation of shatter resistance with important agronomic traits was low, suggesting that it would be feasible to introgress the shatter resistance trait into commercial breeding lines. They also noted the absence of genetic linkage of siliqua strength with other siliqua characters such as short/long siliqua or erect/horizontal siliqua. This suggested that it should also be possible to enhance shatter resistance by combining it these characters. Peng-Fei et al. (2011) investigated inheritance of shatter resistance in $B$. napus by mixed model analysis of parental lines, $F_{1}, B_{1}, R_{B} C_{1}$ and $F_{2}$ generations. They showed that two genes with additive-dominance-epistatic effects plus polygenes with additive-dominance-epistatic effects control shatter resistance. The heritability of two major genes in the $\mathrm{F}_{2}$ and backcross generation ranged from $49.4 \%$ to $50 \%$, suggesting that significant genetic gain can be made through conventional breeding.

Molecular studies of dehiscence zone specific mRNAs have led to isolation of genes which have been considered to be involved in production and regulation of enzymes involved in degeneration of the separation layer upon siliqua ripening (Coupe et al., 1993, 1994; Petersen et al., 1996; Whitelaw et al., 1999). In Arabidopsis, seed shattering is controlled by the several MADS-box and homeodomain genes. Screening of Arabidopsis enhancer or gene trap lines (Ferrándiz, 2002) identified genes involved in DZ differentiation. SHATTERPROOF (SHP1) and SHATTERPROOF (SHP2), previously called AGL1 and AGL5 respectively, are closely related MADS-box genes and are members of a monophyletic clade that also includes AGAMOUS and AGL11 control and promote DZ differentiation at the valve-replum boundary in Arabidopsis (Liljegren et al., 2000). The expression of $\operatorname{sh} 1$ and $\operatorname{sh} 2$ is regulated by AGAMOUS (Savidge et al., 1995), FRUITFULL (Ferrandiz et al., 2000) and REPLUMLESS genes (Roeder et al., 2003). Recently, SHP1 and SHP2 have been shown to play an important role in promoting stigma, style and medial tissue development (Colombo et al., 2010). Another indehiscent mutant gene, ALCATRAZ (ALC), corresponding to the bHLH transcription factor, has been isolated which is involved in the development of the abscission layer in the DZ and direct cell differentiation (Rajani \& Sundaresan, 2001). Girin et al. (2010) reported that the REPLUMPNESS (RPL) gene which acts by limiting the expression of the valve margin identity genes; Shp-1 and Shp-2, INDEHISCENT and ALC to the narrow strips where wall margins will form. In the valves, the FRUITFULL gene is required for post-fertilization development and elongation of the fruit and it acts similarly to the RPL by repressing $\operatorname{Sh} 1 / \operatorname{Sh} p 2$ and IND gene activity.

\section{Breeding B. napus for shatter resistance}

Previous research on evaluation of B. napus germplasm have revealed that there is limited variation in siliqua shatter resistance among current cultivars (Bowman, 1984; Kadkol et al., 1985; Downey \& Röbbelen, 1989; Roberts et al., 2002). Ostergaard et al. (2007) ascribed this to 
the narrow genetic base as a result of breeding focus on 'double-low' cultivars originated from two cultivars, Bronowski and Liho. Also, the recent studies of variation for shatter resistance in germplasm collections (Raman et al., 2011; Wen et al., 2008) support previous reports of a general lack of variation for high levels of shatter resistance in B. napus.

Tolerance to field shattering has been developed in some Australian breeding programs by direct heading of breeding trials and plots as an indirect selection method for shatter resistance. Although the varieties from Australian programs have not been properly characterized for shatter resistance, there appears to be significant improvement in field shatter tolerance in new lines relative to older varieties (Kadkol, 2009; Hossain et al., 2011a). However, further improvement in shatter resistance is required to allow direct heading of commercial crops. The conventional approach to breed B. napus for higher levels of shatter resistance has been based on interspecific hybridisation or resynthesis of $B$. napus using shatter-resistant species from the triangle of $U$. This approach requires several cycles of breeding and selection to overcome chromosomal imbalances and consequent impairment of meiosis and improve fertility of the shatter-resistant segregants. Often, malformation of the siliqua on partly sterile plants results in high siliqua strength.

Prakash and Chopra (1990) carried out interspecific hybridisation between B. juncea and B. napus and were able to isolate a reconstituted $B$. napus plant with complete nondehiscent fruits. This plant had normal meiosis and formed 19 bivalents. However, the seed fertility was very poor $(23 \%)$ although pollen fertility appeared acceptable $(84 \%)$ and this indicated significant chromosomal imbalances which might not have been apparent in meiosis studies. Agnihotri et al. (1990) attempted to transfer shatter resistance from Raphanus into B. napus using Raphanobrassica as the bridging material. This resulted in genetic material with variable fertility. In a Canadian study, lines derived from complex crosses made for development of yellow seeded $B$. napus showed better shatter resistance than standard Canadian B. napus varieties (Wang et al., 2007). Summers et al. (2003) resynthesised B. napus from crosses between $B$. oleracea var. alboglabra and $B$. rapa var. chinensis and developed DK142 that showed superior shatter resistance based on RIT assessments. However, the line turned out to have significantly lower levels of seed set relative to Apex, a commercial check variety. Recently, Banga et al. (2011) transferred shatter resistance from B. carinata to $B$. napus. Hybrid derivatives were characterized cytologically and further evaluated for shatter resistance using delayed harvesting. Anatomical analysis of shatter susceptible lines indicated the presence of DZ comprising thin-walled parenchymatous cell and showed dissolution in 40 days. Whilst shatter resistant genotypes displayed well defined DZ but remained intact and no sign of dissolution of cells or change that could lead to separation of siliquae valve margins from replum. The degree of improvement achieved in siliqua strength in this work is unclear.

Interspecific hybridisation of B. napus with B. rapa var. Brown Sarson and var. Yellow Sarson (Kadkol et al., 1991; Hossain et al., 2011b) has provided promising initial results. Stable segregants with high levels of siliqua strength have been produced with potential to provide harvest shatter resistance. However, further work is required to fully characterise and assess the shatter-resistant selections for meiotic stability, seed set and agronomic traits.

There have been a few reports of genetic transformation for improving shatter resistance in Brassicas. Chandler et al. (2005) over-expressed Sinapis alba MADSB gene, a close homologue 
to FRUITFULL in Arabidopsis, using a transgenic approach in winter and summer oilseed rape plants. The expression of the $M A D S B$ transgene modified the dehiscence zone differentiation and produced indehiscent plants. Ostergaard et al. (2006) showed that ectopic expression of the Arabidopsis FRUITFULL gene in B. juncea is sufficient to produce shatter-resistant Brassica fruit and that the genetic pathway leading to valve margin specification is conserved between Arabidopsis and Brassica. Studies have shown that transgenic fruit produced this way were completely shatter-resistant and were too tough for a combine harvester to thrash (Ferrandiz et al., 2000; Vancanneyt et al., 2003; Ostergaard et al., 2006). This is possibly because of the loss of the basic siliqua structure with valves and sutures that facilitates siliqua rupture. Authors suggested that the use of mutated forms of FUL or RNAi techniques to inactivate valve margin identity genes will probably prove useful in the fine-tuning of the degree of shatter resistance. Although these studies have been unsuccessful in producing the correct anatomical phenotype, they demonstrate a genetic strategy that can be used for improving shatter resistance.

\subsection{Targeting Induced Local Lesions IN Genomes (TILLING)}

The TILLING approach has been utilized for a large number of plants such as in Arabidopsis, wheat, barley, maize, lotus and B. napus (Comai et al., 2004; Slade et al., 2005; Slade \& Knauf, 2005; Dreyer et al., 2007). The major advantage of this approach is the identification of mutants in target genes without genetic transformation. It allows the identification of single base-pair allelic variation in a target gene in a high throughput manner and may offer an alternative approach to identifying variation in shatter resistance among B. napus cultivars. Using this approach, Laga et al. (2011) achieved down-regulation of IND (indehiscent) gene which led to an indehiscence in B. napus, however, siliquae had a tube -like phenotype and did not rupture during mechanical harvesting obviously due to the loss of the valve and DZ structure similar to the transgenic canola discussed above. Use of a reverse genetics approach has produced an agronomically desirable phenotype that has optimal levels of seed shatter reduction. This study isolated and combined a set of mutant (null, weak and dominant negative) IND allele combinations that generated a range of seed shattering levels from natural shattering to pods that were shatter-resistant. Mutant plants displayed a range of reduction in shattering (5 to 15\%) depending upon the combination of mutations used. This variation is being utilized for variety development. However, the method of screening for shatter resistance is unclear.

\subsection{Molecular marker assisted breeding for shatter resistance}

Identification of markers for shatter resistance in B. napus has not been reported extensively in the published literature due to lack of 'useful' variation for this trait in B. napus germplasm. Mongkolporn et al. (2003) utilized bulk segregant analysis (BSA) and identified three RAPD markers in an $F_{2}$ population derived from Torch $X$ DS17D. Two of these markers (RAC- $3_{900}$ and RX-7 1000 ) were linked to the sh1 and sh2 major genes for shatter resistance. RAPD marker SAC-20 $0_{1300}$ showed a complete linkage with dominant alleles $\mathrm{SH} 1$ and $\mathrm{SH} 2$ for shatter susceptibility. The authors suggested it is likely that the recessive alleles, sh1 and sh2, could have originated from independent mutations at two duplicate loci during the evolution of B. rapa. The marker linked to the dominant alleles can be used for markerassisted selection (MAS), once validated in genetically diverse backgrounds. Mongkolporn 
et al. (2003) did not determine the chromosomal location of the loci associated with shatter resistance and this will require further research.

Association mapping (AM) is a promising new strategy for identification of markers for shatter resistance. AM approach is based upon the principle that linkage disequilibrium is maintained between loci over many generations in a given gene pool. Association mapping has been used for discovery and validation of trait-marker associations identified in the classical quantitative trait loci (QTL) mapping for loci associated with blackleg resistance, flowering time, leaf traits, seed phytate content in rapeseed (Jestin et al., 2010; Raman et al., 2010; Raman et al., 2011; Zhao et al., 2007). AM overcomes the major limitations of the QTL analysis that utilize bi-parental populations such as doubled haploids and recombinant inbred lines, as it surveys a large number of alleles at one locus and saves resources and time required to construct purpose designed 'mapping and validation' populations derived from structured biparental crosses.

Association mapping was used by Raman et al. (2011) to identify loci for shatter resistance in 188 genotypes of Brassica napus, B. rapa, B. juncea and B. carinata. These lines were phenotyped for siliqua strength using the pendulum method (Kadkol 2009). All accessions were genotyped with 1513 markers based upon Diversity Array Technology (DArT), Simple Sequence Repeats (SSR) and candidate genes that are reported to be involved in shatter resistance. Association analysis revealed that 150 markers were significantly associated $(P<0.05)$ by the mixed linear model whereas the generalized linear model detected a total of 266 markers showing significant associations with rupture energy. Significantly associated markers were located on chromosomes A1, A2, A4, A6, A7, A8, A10, C2, C3, C5, C8 and C9. These results are consistent with the findings of a comprehensive transcriptome analysis of silique development and dehiscence in Arabidopsis and Brassica (Jaradat et al 2010). This study identified 131 cell wall related genes and 112 transcription factors that may be involved in silique dehiscence. Raman et al (2011) utilized markers that were largely based upon Diversity Array Technology. The majority of these markers have not been genetically mapped yet on the linkage maps of Brassica napus. It is possible that many DArT markers may be cosegregating and therefore map on the same loci. Previous studies have shown that B. napus genome has several chromosome rearrangements and therefore some of the DArT markers may represent to multiple copies of the same gene. Validation and fine mapping of these genomic regions, utilizing structured (doubled haploid or intercross) populations, will allow identification of candidate genes and/or their pathways associated with shatter resistance. The genes/QTLs identified in this work would mainly include loci that influence biochemical processes leading to formation of a separation layer in the $\mathrm{DZ}$ and its degradation at ripening.

\section{Conclusions}

Resistance to shatter is an important trait for B. napus improvement. It is a difficult trait to measure and breed into adapted germplasm and requires multiple years of selection and screening. To date, various breeding approaches have been attempted for improving shatter resistance of $B$. napus, mainly through interspecific hybridization or resynthesis of $B$. napus using shatter-resistant species from the triangle of U. In recent years, the power of highdensity genetic maps and candidate gene studies in Brassica crops have demonstrated that an understanding of the number of genes underpinning the trait and their mode(s) of inheritance 
is important for further progress. In addition, an understanding of the potential of environment to impact on genetics is also required for the successful introduction of this trait into commercial oilseed rape. This information will greatly enhance breeding efficiency by identifying associated QTL or development and use of molecular markers for marker assisted selection.

Field screening using delayed harvest and visual assessments has been widely used to evaluate pod shatter resistance. It still remains the simplest way to get an approximate understanding of the shatter susceptibility of a large subset of lines. However, such assessments may be somewhat unreliable due to large environmental influences and subjective due to the vague boundaries of the assessment criteria. The development of pendulum method and the associated software facilitating rapid tests of shatter resistance have made it possible to characterize large germplasm collections in an objective way.

\section{Future approaches in incorporating shatter resistance}

To date, various approaches have been attempted for improving shatter resistance of $B$. napus, including indirect selection in breeding programs by direct heading, interspecific hybridization and also transformation with genes from other species. Breeding and selection within the species has limited potential due to the low genetic variation for the trait but could still result in development of varieties that are tolerant to field shattering.

To achieve higher levels of shatter resistance, it would be necessary to obtain siliqua strength levels that are available only in other species such as B. rapa and B. juncea. Although the reported attempts have generally not demonstrated complete success, interspecific hybridization could still achieve transfer of shatter resistance into B. napus combined with genetic stability, normal meiosis, and complete fertility together with absence of association with yield negative traits. The power of interspecific hybridization as a means of incorporating useful traits has been demonstrated in B. napus notably for blackleg resistance (Crouch et al., 1994) and yellow seed colour (Relf-Eckstein et al., 2007) but such work often needs a consistent, targeted breeding program over several generations after the initial isolation of the segregates to improve genetic stability and fertility. Molecular marker technology, such as marker assisted backcrossing would be very important for efficient development of shatter-resistant commercial cultivars upon achievement of successful incorporation of shatter resistance into B. napus.

Genetic engineering offers a promising a alternative approach for developing shatterresistant $B$. napus in view of the advances in research on biology of shattering in Arabidopsis. However, shatter-resistant transgenics developed to date appear to have radically altered siliqua anatomy such that valve differentiation, DZ structure and consequently threshability are lost. Further research could develop mutations that retain valve differentiation and siliqua DZ structure whilst eliminating the separation layer similar to the anatomical phenotype of the Brown and Yellow Sarson varieties.

\section{References}

Agnihotri, A., Shivanna, K.R., Raina, S.N., Lakshmikumaran, M., Prakash, S. and Jagannathan, V., 1990. Production of Brassica napus x Raphanobrassica hybrids by 
embryo rescue: an attempt to introduce shattering resistance into B. napus. Plant Breeding, 105: 292-299.

Banga, S, Kaur, G, Grewal, N, Salisbury, P.A and Banga, S. S. 2011. Transfer of resistance to seed shattering from Brassica carinata to B. napus. Proceeding of the $13^{\text {th }}$ International Rapeseed Congress, Prague, Czach Republic, pp 863-866.

Bowman, J.G., 1984. Commercial oilseed rape breeding. Aspects of Applied Biology, 6: 31-36.

Brown, J., Brown, A.P., Davies, J.B. and Erickson, D., 1997. Intergeneric hybridization between Sinapis alba and Brassica napus. Euphytica, 93: 163-168.

Bruce, D.M., Farrent, J.W., Morgan, C.L. and Child, R.D., 2002. Determining the oilseed rape pod strength needed to reduce seed loss due to pod shatter. Biosystems Engineering, 81 (2): 179-184.

Chandler, J., Corbesier, L., Spielmann, P., Dettendorfer, J., Stahl, D., Apel, K. and Melzer, S., 2005. Modulating flowering time and prevention of pod shatter in oilseed rape. Molecular Breeding, 15: 87-94.

Chauvaux, N., Child, R., John, K., Ulvskov, P., Borkhardt, B., Prinsen, E. and Van Onckelen, H.A., 1997. The role of auxin in cell separation in the dehiscence zone of oilseed rape pods. Journal of Experimental Botany, 48: 1423-1429.

Child, R.D., Chauvaux, N., John, K., Ulvskov, P. and Van Onckelen, H.A., 1998. Ethylene biosynthesis in oilseed rape pods in relation to pod shatter. Journal of Experimental Botany, 49: 829-838.

Child, R.D. and Evans, D.E., 1989. Improvement of recoverable yields in oil seed rape (Brassica napus) with growth retardants. Aspects of Biology, 23: 135-143.

Child, R.D. and Huttly, A., 1999. Anatomical variation in the dehiscence zone of oilseed rape pods and its relevance to pod shatter. In: Proceedings of the $10^{\text {th }}$ International Rapeseed Congress, Canberra, Australia. 1999.

Child, R.D., Summers, J.E., Babij, J., Farrent, J.W. and Bruce, D.M., 2003. Increased resistance to pod shatter is associated with changes in the vascular structure in pods of a resynthesised Brassica napus line. Journal of Experimental Botany, 54: 1919-1930.

Child, R.D., Summers, J.E., Farrent, J.W., Babij, J. and Bruce, D.M., 2003. Variation in resistance to pod shatter and underlying mechanism in the resynthesised B. napus line DK142. In: Proceedings of the 11 $11^{\text {th }}$ International Rapeseed Congress, Copenhagen, Denmark. 6-10 July 2003, pp. 402-404.

Colombo, M., Brambilla, V., Marcheselli, R., Caporali, E., Kater, M.M. and Colombo, L., 2010. A new role for the SHATTERPROOF genes during Arabidopsis gynoecium development. Developmental Biology, 337: 294-302.

Comai, L., Young, K., Till, B.J., Reynolds, S.H., Greene, E.A., Codomo, C.A., Enns, L.C., Johnson, J.E., Burtner, C., Odden, A.R. and Henikoff, S., 2004. Efficient discovery of DNA polymorphisms in natural populations by ecotilling. Plant Journal., 37: 778786.

Coupe, S.A., Taylor, J.E., Isaac, P.G. and Roberts, J.A., 1993. Identification and characterisation of a proline-rich mRNA that accumulates during pod development in oilseed rape (Brassica napus L.). Plant Molecular Biology, 23: 1223-1232.

Coupe, S.A., Taylor, J.E., Isaac, P.G. and Roberts, J.A., 1994. Characterisation of a mRNA that accumulates during development of oilseed rape pods. Plant Molecular Biology, 24: 223-227. 
Crouch, J. H., Lewis, B. G. and Mithen, R. F., 1994. The effect of A genome substitution on the resistance of Brassica napus to infection by Leptosphaeria maculans. Plant Breeding 112: $265-278$.

Dinneny, J.R. and Yanofsky, M.F., 2004. Drawing lines and borders: how the dehiscent fruit of Arabidopsis is patterned. BioEssays, 27: 42-49.

Downey, R.K. and Röbbelen, G. (1989). Oilseed crops of the world: their breeding and utilisation, U.S.A: McGraw-Hill Publishing Company.

Dreyer, F., Frauen, M., Leckband, G., Milkowski, C. and Jung, C. 2007. An EMS population of Brassica napus L. for TILLING. The 12th International Rapeseed Congress, Wuhan, China, 26-3003 Presentation BO-2-8.

FAOSTAT (2011) Available at http//:apps.fao.org/defalt.htm.

Ferrándiz, C., 2002. Regulation of fruit dehiscence in Arabidopsis. Journal of Experimental Botany, 53 (1): 2031-2038.

Ferrándiz, C., Liljegren, S.J. and Yanofsky, M.F., 2000. Negative regulation of the SHATTERPROOF genes by FRUITFULL during Arabidopsis fruit development. Science, 289: 436-438.

Girin, T., Stephenson, P., Goldsack, C.M.P., Kempin, S.A., Perez, A., Pires, N., Sparrow, P.A., Wood, T.A., Yanofsky, M.F., and Oestergaard, L., 2010. Brassicaceae INDEHISCENT genes specify valve margin cell fate and repress replum formation. The Plant Journal, 63: 329-338.

Gulden, R.H., Shirtliffe, S.J. and Thomas, A.G., 2003. Secondary seed dormancy prolongs persistence of volunteer canola in western Canada. Weed Science., 51: 904-913.

Hossain, S., Kadkol G. P. and Salisbury P. A., 2011a. Pod shatter resistance evaluation in Australian cultivars of Brassica napus. In: Proceedings of the $13^{\text {th }}$ International Rapeseed Congress, Prague, Czech Republic. 05-09 June 2011, pp 280.

Hossain, S., Kadkol G. P. and Salisbury P. A., 2011b. Shatter-resistant canola germplasm from interspecific hybridization - a progress report. In: Proceedings of the $17^{\text {th }}$ Australian Research Assembly on Brassicas Conference, Wagga Wagga NSW Australia, August 2011. pp 42-44.

Jakubiec, J. and Growchowski, L., 1963. Polowa i laboratoryjna ocena odporuosci dwoch odmian rzepaku jarego na pekanie tuszczyn. Rolnictwo, Warszawa, 7: 49-65.

Jenkins, E.S., Paul, W., Coupe, S.A., Bell, S.J., Davies, E.C. and Roberts, J.A., 1996. Characterisation of an mRNA encoding a polygalacturonase expressed during pod development in oilseed rape (Brassica napus L.). Journal of Experimental Botany, 47: 111-115.

Jaradat, M. R., Ruegger, M., Bowling, A., Butler, H., Sun, Y., Skokut, T., and cutler, A. 2010. A comparative transcriptome analysis of silique development and dehiscence in Arabidopsis and Brassica integerating genotypic, interspecies and developmental comparisions. Proceeding of the 17th Crucifer Genetics Workshop, Sep 5-9th , 2010, Saskatoon, Canada, pp 103

Jestin, C., Lodé, M., Vallée, P., Domin, C., Falentin, C., Horvais, R., Coedel, S., ManzanaresDauleux, M. and Delourme, R., 2010. Association mapping of quantitative resistance for Leptosphaeria maculans in oilseed rape (Brassica napus L.). Molecular Breeding, 1-17.

Josefsson, E., 1968. Investigations on shattering resistance of cruciferous oil crops. Z . Pflanzenzuchtg, 59: 384-396. 
Johnson-Flanagan, A.M., and Spencer, M.S., 1994. Ethylene production during the development of mustard (Brassica juncea) and canola (Brassica napus) seed. Plant Physiology, 106: 601-606.

Kadkol, G.P., 2009. Brassica shatter-resistance research update. In: Proceedings of the 16th Australian Research Assembly on Brassicas Conference, Ballarat Victoria. 14-16 September 2009, pp. 104-109.

Kadkol, G.P., MacMillan, R.H., Burrow, R.P. and Halloran, G.M., 1984. Evaluation of Brassica genotypes for resistance to shatter. I. Development of a laboratory test. Euphytica, 33: 63-73.

Kadkol, G.P., Halloran, G.M. and MacMillan, R.H., 1985. Evaluation of Brassica genotypes for resistance to shatter. II. Variation in siliqua strength within and between accessions. Euphytica, 34: 915-924.

Kadkol, G.P., Beilharz, V.C., Halloran, G.M. and MacMillan, R.H., 1986a. Anatomical basis of shatter resistance in the Oilseed Brassicas. Australian Journal of Botany, 34: 595601.

Kadkol, G.P., Halloran, G.M. and MacMillan, R.H., 1986b. Inheritance of siliqua strength in Brassica campestris L. I. Studies of $F_{2}$ and backcross populations. Canadian Journal of Genetical Cytology, 28: 365-373.

Kadkol, G.P., Halloran, G.M. and MacMillan, R.H., 1986c. Inheritance of siliqua strength in Brassica campestris L. II. Quantitative genetic analysis. Canadian Journal of Genetical Cytology, 28: 563-567.

Kadkol, G.P., Halloran, G.M. and MacMillan, R.H., 1989. Shatter resistance in crop plants. Critical Reviews in Plant Science, 8: 169-188.

Kadkol, G.P., MacMillan, R.H. and Halloran, G.M., 1991. Breeding canola for shatter resistance - a progress report. In: Proceedings of the $8^{\text {th }}$ Australian Research Assembly on Brassicas, Horsham, Victoria. 1-3 October 1991, pp. 135-141.

Laga, B., Stevens, M., Haesendonckx, B., Standaert, E. and Crommar, K., 2011. A reverse genetics approach allows fine-tuning of seed shatter reduction in canola (Brassica napus) to optimal levels. Proceeding of the 13th International Rapeseed Congress, Prague, Czach Republic, pp 905

Liljegren, S.J., Ditta, G.S., Eshed, Y., Savidge, B., Bowman, J.L. and Yanofsky, M.F., 2000. SHATTERPROOF MADS-box genes control seed dispersal in Arabidopsis. Nature, 404: 766-770.

Liu, X-Y., MacMillan, R.H. and Burrow, R.P., 1994. Pendulum test for evaluation of the rupture strength of seed pods. Journal of Texture Studies, 25 (2): 179-189.

Loof, B . and Jonsson, R., 1970 . Resultat av undersokningar rorande drasfastheten hos raps. Sverig. Utsadesforen. Tidskr, 80: 193-205.

MacLeod, J. (1981). 'Harvesting' in Oilseed Rape, Cambridge: Agricultural Publishing, pp 107-119.

Meakin, P.J. and Roberts, J.A., 1990a. Dehiscence of fruit in oilseed rape (Brassica napus L.), I. Anatomy of pod dehiscence. Journal of Experimental Botany, 41: 995-1002.

Meakin, P.J. and Roberts, J.A., 1990b. Dehiscence of fruit in oilseed rape (Brassica napus L.), II. The role of cell wall degrading enzymes and ethylene. Journal of Experimental Botany, 41: 1003-1011. 
Meakin, P.J. and Roberts, J.A., 1991. Anatomical and biochemical changes associated with the induction of oilseed rape (Brassica napus) pod dehiscence by Dasineura brassicae (Winn.). Annals of Botany, 67: 193-197.

Mongkolporn, O., Kadkol, G.P., Pang, E.C.K. and Taylor, P.W.J., 2003. Identification of RAPD markers linked to recessive genes conferring siliqua shatter resistance in Brassica rapa. Plant Breeding, 122: 479-484.

Morgan, C.L., Bruce, D.M.., Child, R., Ladbrooke, Z.L. and Arthur, A.E., 1998. Genetic variation for pod shatter resistance among lines of oilseed rape developed from synthetic B. napus. Field Crops Research, 58: 153-165.

Morgan, C.L., Ladbrooke, Z.L., Bruce, D.M., Child, R., and Arthur, A.E., 2000. Breeding oilseed rape for pod shattering resistance. Journal of Agricultural Science, Cambridge, 135: 347-359.

Morgan, C., Bavage, A., Bancroft, I., Bruce, D., Child, R., Chinoy, C., Summers, J. and Arthur, E., 2003. Using novel variation in Brassica species to reduce agricultural inputs and improve agronomy of oilseed rape - a case study in pod shatter resistance. Plant Genetic Resources, 1: 59-65.

Nemhauser, J., feldmann, L.J. and Zambryski, P.C., 2000. Auxin and ETTIN in Arabidopsis gynoecium morphogenesis. Development, 127: 3877-3888.

Ostergaard, L., Borkhardt, B. and Ulvskov, P. (2007). 'Dehiscence' in Plant Cell Separation and Adhesion, eds. Roberts, J.A. and Gonzalez-Carranza, Z.H., Victoria: Blackwell Publishing, pp. 137-163.

Ostergaard, L., Kempin, S.A., Bies, D., Klee, H.J. and Yanofsky, M.F. 2006. Pod shatterresistant Brassica fruit produced by ectopic expression of the FRUITFULL gene. Plant Biotechnology Journal, 4: 45-51.

Pekrun, C., Lutman, P.J.W. and Baeumer, K., 1996. Introduction of secondary dormancy in rape seeds (Brassica napus L.) by prolonged imbibition under conditions of water stress or oxygen deficiency in darkness. Eur. J. Agron., 6: 245-255.

Peng, P. Li, Y., Mei, D., Li, Y., Xu, Y. and Hu, Q., 2011. Evaluation and genetic analysis of pod shattering resistance in Brassica napus. In: Proceedings of the $13^{\text {th }}$ International Rapeseed Congress, Prague, Czech Republic. 05-09 June 2011, pp. 185.

Petersen, M., Sander, L., Child, R. van Onckelen, H., Ulvskov, P. and Borkhardt, B., 1996. Isolation and characterisation of a pod dehiscence zone-specific polygalacturonase from Brassica napus. Plant Molecular Biology, 31: 517-527.

Picart, J.A. and Morgan, D.G., 1984. Pod development in relation to pod shattering. Aspects of Applied Biology, 6: 101-110.

Prakash, S. and Chopra, V.L., 1990. Reconstruction of allopolyploid Brassicas through nonhomologous recombination: introgression of resistance to pod shatter in Brassica napus. Genetical Research, Cambridge, 56: 1-2.

Price, J.S., Hobson, R.N., Neale, M.A. and Bruce, D.M., 1996. Seed losses in commercial harvesting of oilseed rape. Journal of Agricultural Engineering Research, 65: 183-191.

Rajani, S. and Sundaresan, V., 2001. The Arabidopsis myc/bHLH gene ALCATRAZ enables cell separation in fruit dehiscence. Current Biology, 11: 1914-1922.

Raman, R., Raman, H., Kadkol, G.P., Coombes, N., Taylor, B. and Luckett, D., 2011. Genome-wide association analyses of loci for shatter resistance in Brassicas. In: Proceedings of the Australian Research Assembly on Brassicas, Wagga Wagga, NSW, Australia, pp 36-41. 
Raman, H., Stodart, B., Ryan, P., Delhaize, E., Emberi, L., Raman, R., Coombes, N. and Milgate, A., 2010. Genome wide association analyses of common wheat (Triticum aestivum L) germplasm identifies multiple loci for aluminium resistance. Genome, 53:957-966.

Relf-Eckstein, J., Rakow, G.F.W., Rode, D.A. and Gugel, R.K., 2007. Agronomic performance and blackleg disease reactions of yellow-seeded Brassica napus canola., GCIRC 12th International Rapeseed Congress, Wuhan City, Hubei Province, China, March 26-30, 2007, Vol. IV, pp. 133-136.

Roberts, J.A., Elliott, K.A. and Gonzalez-Carranza, Z.H., 2002. Abscission, Dehiscence and other cell separation processes. Annual Reviews in Plant Biology, 53: 131-158.

Roeder, A.H.K., Ferrándiz, C. and Yanofsky, M.F., 2003. The role of the REPLUMLESS homeodomain protein in patterning the Arabidopsis fruit. Current Biology, 13: 16301635.

Sander, L., Child, R., Ulvskov, P., Albrechtsen, M. and Borkhardt, B., 2001. Analysis of a dehiscence zone endo-polygalacturonase in oilseed rape (Brassica napus) and Arabiopsis thaliana: evidence for roles in cell separation in dehiscence and abscission zones, and in stylar tissues during pollen tube growth. Plant Molecular Biology, 46: 469-479.

Slade, A.J., Fuerstenberg, S.I., Loeffler, D., Steine, M.N. and Facciotti, D., 2005. A reverse genetic, nontransgenic approach to wheat crop improvement by TILLING. Nature Biotechnology, 23: 75-81.

Slade, A.J. and Knauf, V.C., 2005. TILLING moves beyond functional genomics into crop improvement. Transgenic Research, 14:109-115.

Sohlberg, J., Myrenas, M., Kuusk, S., Lagercrantz, U., Kowalczyk, M., Sandberg, G. and Sundberg, E., 2006. STY1 regulates auxin homeostasis and affects apical-basal patterning of the Arabidopsis gynoecium. Plant Journal, 47: 112-123.

Sorefan, K., Girin, T., Liljegren, S.J., Ljung, K., Robles, P., Galvan-Ampudia, C.S., Offringa, R., Friml, J., Yanofsky, M.F. and Ostergaard, L., 2009. A regulated auxin minimum is required for seed dispersal in Arabidopsis. Nature, 459: 583-587.

Squires, T.M., Gruwel, M.L.H., Zhow, R., Sokhansanj, S., Abrams, S.R. and Cutler, A.J., 2003. Dehydration and dehiscence in siliques of Brassica napus and Brassica rapa. Canadian Journal of Botany, 81: 248-254.

Summers, J.E., Bruce, D.M., Vancanneyt, G., Redig, P., Werner, C.P., Morgan, C. and Child, R.D., 2003. Pod shatter resistance in the resynthesised Brassica napus line DK142. Journal of Agricultural Science, 140: 43-52.

Tan, X., Zhang, J., Zhang, Z., Zhou, J., Jiang, S., Qi, C. and Li, J., 2007. Quantitative determination of the strength of rapeseed pod dehiscence. In: Proceedings of the $12^{\text {th }}$ International Rapeseed Congress, Wuhan, China. 26-30 March 2007, pp. 280-283.

Tomaszewski, Z. and I . Koczowska, I., 1971. Metoda hodowli rzepiku ozimego TK-67. Biuletyn Institutu Hodowli i Aklimatyzacji Roslin, 5: 73-75.

Tys, J., Stasiak, H., Borychowski, A. and Rybacki, R., 2007. Crack resistance of pods in some varieties of winter rapeseed. In: Proceedings of the $12^{\text {th }}$ International Rapeseed Congress, Wuhan, China. 26-30 March 2007, pp. 420-422.

Vancanneyt, G., Redig, P., Child, R., Yanofsky, M. and Botterman, J., 2003. Podshatter resistance: from gene function validation in Arabidopsis towards a productivity trait 
in oilseed rape. In: Proceedings of the $11^{\text {th }}$ International Rapeseed Congress, Copenhagen, Denmark. 6-10 July 2003, pp. 79-81.

Voskerusa, J., 1971. Z vyfesenych vyzkumnych ukolu v odvetvi olejnin. Vestnik Ceskoslovenske Akademie Zemedelskie 18: 538-541.

Fan., 2011. Production and characterization of interspecific somatic hybrids between Brassica oleracea var. botrytis and B. nigra and their progenies for the selection of advanced pre-breeding materials. Plant Cell Rep, 1-11. doi:10.1007/s00299-011-1088-9

Wang, R., Ripley, V.L. and Rakow, G., 2007. Pod shatter resistance evaluation in cultivars and breeding lines of Brassica napus, B. juncea and Sinapis alba. Plant Breeding, 126: 588-595.

Wen, Y.C., Fu, T.D., Tu, J.X., Ma, C.Z., Shen, J.X. and Zhang, S.F., 2008. Screening and analysis of resistance to siliquae shattering in rape (Brassica napus L.). Acta Agronomic Sinica, 34:163-166.

Whitelaw, C.A., Paul, W., Jenkins, E.S., Taylor, V.M. and Roberts, J.A., 1999. An mRNA encoding a response regulator protein from Brassica napus is up-regulated during pod development. Journal of Experimental Botany, 50: 335-341.

Zhao, J., Paulo, M-J., Jamar, D., Lou, P., van Eeuwijk, F., Bonnema, G., Vreugdenhil, D. and Koornneef, M., 2007. Association mapping of leaf traits, flowering time, and phytate constent in Brassica rapa. Genome, 50:963-973. 


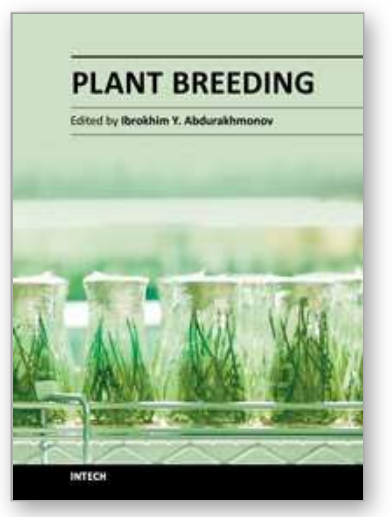

\author{
Plant Breeding \\ Edited by Dr. Ibrokhim Abdurakhmonov
}

ISBN 978-953-307-932-5

Hard cover, 352 pages

Publisher InTech

Published online 11, January, 2012

Published in print edition January, 2012

Modern plant breeding is considered a discipline originating from the science of genetics. It is a complex subject, involving the use of many interdisciplinary modern sciences and technologies that became art, science and business. Revolutionary developments in plant genetics and genomics and coupling plant "omics" achievements with advances on computer science and informatics, as well as laboratory robotics further resulted in unprecedented developments in modern plant breeding, enriching the traditional breeding practices with precise, fast, efficient and cost-effective breeding tools and approaches. The objective of this Plant Breeding book is to present some of the recent advances of 21 st century plant breeding, exemplifying novel views, approaches, research efforts, achievements, challenges and perspectives in breeding of some crop species. The book chapters have presented the latest advances and comprehensive information on selected topics that will enhance the reader's knowledge of contemporary plant breeding.

\title{
How to reference
}

In order to correctly reference this scholarly work, feel free to copy and paste the following:

S. Hossain, G.P. Kadkol, R. Raman, P.A. Salisbury and H. Raman (2012). Breeding Brassica napus for Shatter Resistance, Plant Breeding, Dr. Ibrokhim Abdurakhmonov (Ed.), ISBN: 978-953-307-932-5, InTech, Available from: http://www.intechopen.com/books/plant-breeding/breeding-brassica-napus-for-shatter-resistance

\section{INTECH}

open science | open minds

\author{
InTech Europe \\ University Campus STeP Ri \\ Slavka Krautzeka 83/A \\ 51000 Rijeka, Croatia \\ Phone: +385 (51) 770447 \\ Fax: +385 (51) 686166 \\ www.intechopen.com
}

\author{
InTech China \\ Unit 405, Office Block, Hotel Equatorial Shanghai \\ No.65, Yan An Road (West), Shanghai, 200040, China \\ 中国上海市延安西路65号上海国际贵都大饭店办公楼405单元 \\ Phone: +86-21-62489820 \\ Fax: $+86-21-62489821$
}


(C) 2012 The Author(s). Licensee IntechOpen. This is an open access article distributed under the terms of the Creative Commons Attribution 3.0 License, which permits unrestricted use, distribution, and reproduction in any medium, provided the original work is properly cited. 